\title{
Retraction Note: Oxycodone versus morphine for analgesia after laparoscopic endometriosis resection
}

Lijun Niu' ${ }^{1}$ Lihong Chen², Yanhua Luo ${ }^{3}$, Wenkao Huang ${ }^{4}$ and Yunsheng $\mathrm{Li}^{i^{*}}$

Retraction Note: BMC Anesthesiol 21, 194 (2021)

https://doi.org/10.1186/s12871-021-01417-3

The Editor has retracted this article because after obtaining approval for this clinical trial from the Institutional Ethical Review Committee for Clinical Trials of The First Affiliated Hospital of Sun Yat-sen University the authors made changes to the protocol without obtaining the Committee's approval. All authors agree to this retraction.

\section{Author details}

${ }^{1}$ Department of Anesthesiology, The First Affiliated Hospital, Sun Yat-sen University, No.58, Zhongshan 2nd Road, Guangzhou 510080, China. ${ }^{2}$ Department of Anesthesiology, The Six Affiliated Hospital, Sun Yat-sen University, No. 26, Erheng Road, Guangzhou 510655, China. ${ }^{3}$ Department of Anesthesiology, Zhongshan Ophthalmic Center, Sun Yat-Sen University, No.54 Xianlie South Road, Guangzhou 510060, China. ${ }^{4}$ Department of Anesthesiology, Nanfang Hospital, Southern Medical University, 1838 Guangzhou Avenue North, Guangzhou, China.

Published online: 11 December 2021

\section{Publisher's Note}

Springer Nature remains neutral with regard to jurisdictional claims in published maps and institutional affiliations. original author(s) and the source, provide a link to the Creative Commons licence, and indicate if changes were made. The images or other third party material in this article are included in the article's Creative Commons licence, unless indicated otherwise in a credit line to the material. If material is not included in the article's Creative Commons licence and your intended use is not permitted by statutory regulation or exceeds the permitted use, you will need to obtain permission directly from the copyright holder. To view a copy of this licence, visit http://creativecommons.org/licenses/by/4.0/. The Creative Commons Public Domain Dedication waiver (http://creativecommons.org/publicdomain/zero/1.0/) applies to the data made available in this article, unless otherwise stated in a credit line to the data. 